\title{
THE EFFECT OF THE IMPLEMENTATION OF ACCOUNTING INFORMATION SYSTEMS AND INTERNAL CONTROL ON EMPLOYEE PERFORMANCE
}

\author{
Ari Bramasto*1, Ridwan Hana Adiwiguna² \\ Langlangbuana University, Indonesia ${ }^{* 12}$ \\ arya bravo@yahoo.com ${ }^{* 1}$, ridwanhana14@gmail.com²
}

\begin{abstract}
This study aims to determine the influence of application accounting Information system and internal control to employee performance at PT BPR Kerta Raharja Bandung Regency. This study using descriptive research methods and verification research methods. The sampling technique used was purposive sampling by determine appropriate specific criteria with the research. The statistic analysis used in this study is path analysis and hypothesis testing. The number of population in this study was 230 respondents with the sample used 48 employee PT BPR Kerta Raharja. Based on the research conducted, it can be seen that application of accouting system has no effect to employee performance but internal control has a significant effect on employee performance.
\end{abstract}

Keywords: Accounting Information System, Internal Control, Employee Performance

\section{INTRODUCTION}

The Accounting Information System is an information system that converts business transaction data into useful information for its users. One of the important functions of the accounting information system is internal control. One of the objects of internal control is company performance and individual performance in it. According to Mangkunegara (2002) performance is defined as the quality of the work achieved by employees in carrying out their duties in accordance with their responsibilities. (Suhud, 2015). Internal control is designed and influenced by the entity's board of directors, management, and other personnel to provide reasonable assurance about the achievement of the entity's objectives in the following categories: (1) reliability of financial reporting, (2) operating effectiveness and efficiency, and (3) compliance with regulatory penalties applicable. Internal control consists of policies and procedures designed to give management adequate confidence that the company is achieving its goals and objectives. From the understanding of experts that an internal control is used to help monitor activities within the scope of the company. (Maharani, 2015). The quality of humans as labor is the basic capital in the development period. A quality workforce will produce optimal work results in accordance with their work targets. Humans as workers or employees are an important resource for the company, because they have the talent, energy and creativity that are needed by the company to achieve its goals. On the other hand, human resources have various kinds of needs that they want to fulfill. The desire of employees to meet these needs can motivate someone to do something, including doing work or work. (Taradipa, 2017). In research conducted by Sheilla Puteri Suhud and Abdul Rohman (2015) states that "individual performance variables are significantly influenced by the use of accounting information systems, the quality of accounting information systems and suggestions for supporting accounting information systems". Another research conducted by Lastri Andayani (2016) states that "Based on the results of the test, it is stated that internal control has a statistically positive and significant effect 
on employee performance" at gas stations in the Karanganyar Regency, Central Java. A system that is interconnected to produce information that is useful in making decisions, namely information systems. (Sari, 2017: 3). The process is designed to provide assurance to believe that organizational goals can be achieved through the presentation of reliable financial reporting, compliance with applicable laws and regulations, operational efficiency and effectiveness (Susanto, 2013: 103).

Improved performance is caused by employee effectiveness, so a better system improvement will have an impact on good performance. (Wake up, 2012: 230)

\section{METHODS}

Table 1. Sample of BPR Kerta Raharja Company, Bandung Regency

\begin{tabular}{ll}
\hline Total Employee Share & Total Employee Share \\
\hline Branch head & 4 \\
Customer Service & 16 \\
Teller & 20 \\
Collectors & 8 \\
Total Population & 48 \\
\hline
\end{tabular}

\section{Validity and Reliability Test}

The validity and reliability of research are the main things in increasing the effectiveness of the data collection process. This test is carried out so that the research questionnaire distribution is valid and reliable, which means a measuring tool to obtain data that can be used.

\section{Data analysis technique}

The statistical analysis test research is used to answer problems and test hypotheses that have been formulated using descriptive analysis and path analysis. Descriptive Analysis Descriptive analysis is a study conducted to determine the value of each variable, whether one or more variables are independent without making relationships or comparisons with other
Research Design The method used in this research is descriptive research methods and verification research methods. Population The population in this study were all staff of PT. BPR Kerta Raharja, Bandung Regency, totaling 230 people. Samples Researchers using purposive sampling aim to take several criteria that can answer the questionnaire from the author, here are the criteria determined by the author: Branches that have cash offices Employees who meet the criteria as researchers need, among others: branch heads, customer service, tellers , collector. Based on the criteria determined by the researcher, the sample taken by the researcher was 48 people. The following is a list used by researchers: variables. Path Analysis Path analysis is used to describe and test the relationship between variables in the form of causation. Thus, in the model of the relationship between these variables, there are independent variables which in this case are called exogenous variables (exogenous), and dependent variables which are called endogenous variables (endogenous). By using this path analysis aims to determine the effect of a variable on other variables (the effect of $\mathrm{X} 1$ and $\mathrm{X} 2$ on $\mathrm{Y}$ ). Furthermore, each independent variable ( $\mathrm{X} 1$ and $\mathrm{X} 2$ ) is measured for its influence on these fixed variables to get a picture of the comparison of the most significant effects. Path analysis (path analysis) is described as follows 


\section{Validity and Reliability Test}

The validity and reliability of research are the main things in increasing the effectiveness of the data collection process. This test is carried out

\section{Data analysis technique}

The statistical analysis test research is used to answer problems and test hypotheses that have been formulated using descriptive analysis and path analysis. Descriptive Analysis Descriptive analysis is a study conducted to determine the value of each variable, whether one or more variables are independent without making relationships or comparisons with other variables. Path Analysis Path analysis is used to describe and test the relationship between variables in the form of causation. Thus, in the model of the

\section{RESULTS AND DISCCUTION}

Table 2. Recapitulation of Respondents' Responses Regarding the Application of Accounting Information Systems

\begin{tabular}{|c|c|c|c|c|c|c|c|c|}
\hline \multirow[t]{2}{*}{ No } & \multirow[t]{2}{*}{ Statement } & \multicolumn{5}{|c|}{ Answer Frequency } & \multirow{2}{*}{$\begin{array}{l}\text { Total } \\
\text { Score }\end{array}$} & \multirow[t]{2}{*}{$\%$} \\
\hline & & 5 & 4 & 3 & 2 & 1 & & \\
\hline \multicolumn{9}{|c|}{ Utilization of Computers } \\
\hline 1 & $\begin{array}{l}\text { Existing computers in the company } \\
\text { have been used optimally }\end{array}$ & 5 & 43 & & & & 197 & 10,63 \\
\hline 2 & $\begin{array}{l}\text { Availability of computers is in } \\
\text { accordance with the number of } \\
\text { employees }\end{array}$ & & 22 & 20 & 6 & & 160 & 8,63 \\
\hline 3 & $\begin{array}{l}\text { Available computers already have } \\
\text { specifications according to your needs }\end{array}$ & 9 & 20 & 16 & 3 & & 179 & 9,65 \\
\hline \multicolumn{9}{|c|}{ Internet means } \\
\hline 4 & $\begin{array}{l}\text { The internet network used is running } \\
\text { well and there are no obstacles (lag) }\end{array}$ & 9 & 25 & 11 & 3 & & 184 & 9,92 \\
\hline 5 & $\begin{array}{l}\text { Internet (wifi) support is available as } \\
\text { needed. }\end{array}$ & 6 & 27 & 15 & & & 183 & 9,87 \\
\hline 6 & $\begin{array}{l}\text { Internet speed is sufficient to support } \\
\text { employee work. }\end{array}$ & 9 & 22 & 14 & 3 & & 181 & 9,76 \\
\hline \multicolumn{9}{|c|}{ Quality of banking applications } \\
\hline 7 & The application provided is easy to use & 9 & 30 & 9 & & & 192 & 10,36 \\
\hline 8 & $\begin{array}{l}\text { The application runs well and is not } \\
\text { easy to error }\end{array}$ & 7 & 28 & 12 & 1 & & 185 & 9,99 \\
\hline 9 & $\begin{array}{l}\text { The application used has a data base } \\
\text { that can store data properly. }\end{array}$ & 15 & 15 & 18 & & & 189 & 10,19 \\
\hline \multirow[t]{2}{*}{10} & $\begin{array}{l}\text { The available applications have a code } \\
\text { for each user. }\end{array}$ & 18 & 24 & 6 & & & 204 & 11 \\
\hline & Total & & & & & & 1854 & 100 \\
\hline
\end{tabular}

Submitted: November 03, 2020; Accepted: November 10, 2020;

Published: December 16, 2020; Website: http://journalfeb.unla.ac.id/index.php/jasa 
Source: Processed Data, 2019

Based on the above recapitulation, it can be concluded that the variable application of this accounting information system is included in the "Agree" category because this variable is in the range of values (interval) ranging from "1632 - 2016". Taken from several entries to respondents regarding the statement answered by the respondent, the available application has a code for each user with a total score of 240 out of 1854 or $11 \%$.

\section{Regarding Intermal Control}

The recapitulation of the results from respondents' responses regarding internal control is as follows:

Table 3. Recapitulation of Respondents' Responses Regarding Internal Control

\begin{tabular}{|c|c|c|c|c|c|c|c|}
\hline \multirow[t]{2}{*}{ No } & \multirow[t]{2}{*}{ Statement } & \multicolumn{4}{|c|}{ Answer Frequency } & \multirow{3}{*}{$\begin{array}{ll} & \text { Total } \\
& \text { Score } \\
1 & \end{array}$} & \multirow[t]{3}{*}{$\%$} \\
\hline & & 5 & 4 & 3 & 2 & & \\
\hline \multicolumn{6}{|c|}{ Risk Assessment } & & \\
\hline 1 & $\begin{array}{l}\text { Existing plans are effective in } \\
\text { reducing the risk of default. }\end{array}$ & 6 & 27 & 12 & 3 & 180 & 13,90 \\
\hline 2 & $\begin{array}{l}\text { Company regulations have } \\
\text { supported the effectiveness of } \\
\text { employees' work }\end{array}$ & 6 & 27 & 15 & & 183 & 14,13 \\
\hline \multicolumn{8}{|c|}{ Control environment } \\
\hline 3 & $\begin{array}{l}\text { The organizational structure in } \\
\text { the company is adequate. }\end{array}$ & 3 & 31 & 11 & 3 & 178 & 13,75 \\
\hline 4 & $\begin{array}{l}\text { The company's vision and } \\
\text { mission have been carried out } \\
\text { well }\end{array}$ & 12 & 27 & 9 & & 195 & 15,06 \\
\hline \multicolumn{8}{|c|}{ Control Activities } \\
\hline 5 & $\begin{array}{l}\text { The tasks given are in } \\
\text { accordance with the } \\
\text { employee's position }\end{array}$ & 8 & 37 & 3 & & 197 & 15,21 \\
\hline 6 & $\begin{array}{l}\text { Employees already understand } \\
\text { the obligations in their } \\
\text { respective duties. }\end{array}$ & 6 & 20 & 22 & & 176 & 13,59 \\
\hline 7 & $\begin{array}{l}\text { The allowances provided by } \\
\text { the company are in } \\
\text { accordance with employee } \\
\text { performance. }\end{array}$ & 3 & 36 & 9 & & 186 & 14,36 \\
\hline \multicolumn{2}{|c|}{ Total } & & & & & 1295 & 100 \\
\hline
\end{tabular}

Source: Processed Data, 2019

Based on the above recapitulation, it can be concluded that the employee performance variable is included in the "Agree" category because this variable falls into the range of values (interval) ranging from "1142.5 - 1411.2". Taken from several respondents regarding the statement answered by the respondent, namely the assignment given is in accordance with the employee's position with a total score of 197 out of 1295 or $15.21 \%$. 


\section{Regarding Employee Performance}

The recapitulation of the results from respondents' responses regarding employee performance is as follows:

Table 4. Recapitulation of Respondents' Responses regarding Employee Performance

\begin{tabular}{|c|c|c|c|c|c|c|c|c|}
\hline \multirow[t]{2}{*}{ No } & \multirow[t]{2}{*}{ Statement } & \multicolumn{5}{|c|}{ Answer Frequency } & \multirow{2}{*}{$\begin{array}{l}\text { Total } \\
\text { Score }\end{array}$} & \multirow[t]{2}{*}{$\%$} \\
\hline & & 5 & 4 & 3 & 2 & 1 & & \\
\hline \multicolumn{9}{|c|}{ Billing } \\
\hline 1 & $\begin{array}{l}\text { The employee's work when billing is } \\
\text { done according to company } \\
\text { procedures }\end{array}$ & 9 & 33 & 6 & & & 195 & 11,30 \\
\hline 2 & $\begin{array}{l}\text { The timeliness in invoicing has been } \\
\text { carried out according to the time } \\
\text { period determined by the company. }\end{array}$ & 6 & 37 & 5 & & & 193 & 11,19 \\
\hline 3 & $\begin{array}{l}\text { The method of billing by employees is } \\
\text { already going well. }\end{array}$ & 6 & 39 & 3 & & & 195 & 11,30 \\
\hline \multicolumn{9}{|c|}{ Input data } \\
\hline 4 & $\begin{array}{l}\text { Employees already understand how } \\
\text { to enter customer data properly. }\end{array}$ & 3 & 33 & $\begin{array}{l}1 \\
2\end{array}$ & & & 183 & 10,61 \\
\hline 5 & $\begin{array}{l}\text { Timely input of data by employees in } \\
\text { accordance with company } \\
\text { regulations. }\end{array}$ & 12 & 27 & 9 & & & 195 & 11,30 \\
\hline \multicolumn{9}{|c|}{ Attitude of employees } \\
\hline 6 & $\begin{array}{l}\text { Employees have solidarity in } \\
\text { teamwork }\end{array}$ & 6 & 33 & 9 & & & 189 & 10,96 \\
\hline 7 & $\begin{array}{l}\text { Every employee has a friendly and } \\
\text { courteous attitude to other fellow } \\
\text { employees }\end{array}$ & 8 & 34 & 3 & 3 & & 191 & 11,07 \\
\hline 8 & $\begin{array}{l}\text { Employees can be respectful towards } \\
\text { their superiors }\end{array}$ & 12 & 30 & 6 & & & 198 & 11,48 \\
\hline \multirow[t]{2}{*}{9} & $\begin{array}{l}\text { Employees have a competent attitude } \\
\text { and are quick to carry out their } \\
\text { assigned tasks. }\end{array}$ & 6 & 30 & $\begin{array}{l}1 \\
2\end{array}$ & & & 186 & 10,78 \\
\hline & Total & & & & & & 1725 & 100 \\
\hline
\end{tabular}

Based on the above recapitulation, it can be concluded that the employee performance variable is included in the "Agree" category because this variable falls into the range of values (interval) ranging from "1468.9 - 1814.4". Taken from several respondents regarding the statements answered by respondents, namely employees can be respectful towards their superiors with a total score of 198 out of 1725 or $11.48 \%$.

\section{Verification Research Results}

The data validity test aims to determine the validity of the questions from the questionnaire proposed by the researcher. This validity test uses the product moment (Pearson correlatio). If rcount is greater than rtable and significant less than 0.05 , then the instrument meets the criteria and is valid. 
Table 5. Validity Test of the Application of Accounting Information Systems

\begin{tabular}{cccccc}
\hline No & Item Pearson & $\begin{array}{c}\text { Pearson } \\
\text { Correlation }\end{array}$ & & rtable & Conclusion \\
\hline 1 & X1_1 & 0,742 & $>$ & 0,285 & Valid \\
2 & X1_2 & 0,312 & $>$ & 0,285 & Valid \\
3 & X1_3 & 0,605 & $>$ & 0,285 & Valid \\
4 & X1_4 & 0,861 & $>$ & 0,285 & Valid \\
5 & X1_5 & 0,648 & $>$ & 0,285 & Valid \\
6 & X1_6 & 0,751 & $>$ & 0,285 & Valid \\
7 & X1_7 & 0,613 & $>$ & 0,285 & Valid \\
8 & X1_8 & 0,381 & $>$ & 0,285 & Valid \\
9 & X1_9 & 0,617 & $>$ & 0,285 & Valid \\
10 & X1_10 & 0,403 & $>$ & 0,285 & Valid \\
\hline
\end{tabular}

Source: Appendix

Based on the results of testing the validity of the data in table $4: 10$. above that the variable $\mathrm{X} 1$ (Application of Accounting Information Systems) shows that all data obtained is valid. This fulfills the requirement that the significant value $r$ count is greater than rtabel, thus all statement items in the questionnaire can be used and can be trusted to collect the necessary data and for further processing.

Table 6. Internal Control Validity Test

\begin{tabular}{lccccc}
\hline No & Item Pearson & $\begin{array}{c}\text { Pearson } \\
\text { Correlation }\end{array}$ & & rtable & Conclusion \\
\hline 1 & X2_1 & 0,757 & $>$ & 0,285 & Valid \\
2 & X2_2 & 0,573 & $>$ & 0,285 & Valid \\
3 & X2_3 & 0,634 & $>$ & 0,285 & Valid \\
4 & X2_4 & 0,885 & $>$ & 0,285 & Valid \\
5 & X2_5 & 0,770 & $>$ & 0,285 & Valid \\
6 & X2_6 & 0,621 & $>$ & 0,285 & Valid \\
7 & X2_7 & 0,633 & $>$ & 0,285 & Valid \\
\hline
\end{tabular}

Source: Appendix

Based on the results of testing the validity of the data in table $4: 11$. above that the variable X2 (Internal Control) shows that all data obtained are valid. This fulfills the requirement that the significant value $r$ count is greater than rtabel, thus all statement items in the questionnaire can be used and can be trusted to collect the necessary data and for further information.

Table 7. Validity Test of Employee Performance Data

\begin{tabular}{|c|c|c|c|c|c|}
\hline No & Item Pearson & $\begin{array}{c}\text { Pearson } \\
\text { Correlation }\end{array}$ & & $r_{\text {table }}$ & Conclusion \\
\hline 1 & $Y \_1$ & 0,713 & $>$ & 0,285 & Valid \\
\hline 2 & $Y^{-} 2$ & 0,749 & $>$ & 0,285 & Valid \\
\hline 3 & $\mathrm{Y}^{-} 3$ & 0,850 & $>$ & 0,285 & Valid \\
\hline 4 & Y_4 & 0,472 & $>$ & 0,285 & Valid \\
\hline 5 & $\mathrm{Y}^{-} 5$ & 0,710 & $>$ & 0,285 & Valid \\
\hline 6 & $\mathrm{Y}^{-6}$ & 0,507 & $>$ & 0,285 & Valid \\
\hline 7 & Y_7 & 0,513 & $>$ & 0,285 & Valid \\
\hline 8 & Y_8 & 0,708 & $>$ & 0,285 & Valid \\
\hline 9 & $\mathrm{Y}^{-} 9$ & 0,708 & $>$ & 0,285 & Valid \\
\hline
\end{tabular}

Source: Appendix

Submitted: November 03, 2020; Accepted: November 10, 2020; 
Based on the results of testing the validity of the data in table $4: 12$. above that the variable $Y$ (Employee Performance) shows that all data obtained is valid. This fulfills the requirement that the significant value $r$ count is greater than rtabel, thus all statement items in the questionnaire can be used and can be trusted to collect the necessary data and for further processing.

\section{Data Reliability Test}

The results of the reliability test on the research instruments can be shown in the table as follows:

Table 8. Data Reliability Test

\begin{tabular}{|c|c|c|c|}
\hline No & Variable & Cronbach Alpha & Conclusion \\
\hline 1 & $\mathrm{X} 1$ & 0,840 & Reliabel \\
\hline 2 & $\mathrm{X} 2$ & 0,876 & Reliabel \\
\hline 3 & Y & 0,907 & Reliabel \\
\hline
\end{tabular}

\section{Source: Appendix}

Based on the table above, all the research variable instruments have a Cronbach Alpha value of more than 0.7, thus it can be concluded that all research variables are reliable.

Table 9. Path Analysis

\section{Correlations}

\begin{tabular}{llcr}
\hline & & $\begin{array}{c}\text { application of accounting } \\
\text { information systems }\end{array}$ & internal control \\
\hline application of & Pearson & 1 &, $765^{* *}$ \\
accounting & Correlatio & & \\
information & $\mathrm{n}$ & &, 000 \\
systems & Sig. (2- & 48 & 48 \\
& tailed) &, $765^{* *}$ & 1 \\
internal control & $\mathrm{N}$ & & \\
& Pearson &, 000 & 48 \\
& Correlatio & & \\
& $\mathrm{n}$ & 48 & \\
& Sig. (2- & tailed) &
\end{tabular}

Based on the table above, it can be illustrated that the relationship between the variables of the accounting information system application (X1) and internal control (X2) has a value of 0.765 , including strong. For more details, the coefficient can be seen in the following figure: 


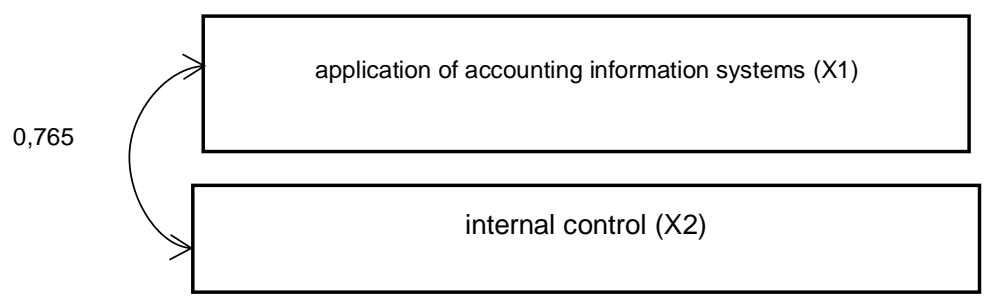

Figure 1. Relationship between independent path coefficient variable

Here are the results of the path coefficient using SPSS

Table 10. Path Coefficient

\section{Coefficients $^{\mathrm{a}}$}

\begin{tabular}{|c|c|c|}
\hline del & $\begin{array}{l}\text { Unstandardiz } \\
\text { d Coefficient }\end{array}$ & $\begin{array}{c}\text { Standardized } \\
\text { Coefficients }\end{array}$ \\
\hline
\end{tabular}

\begin{tabular}{llcccc}
\cline { 4 - 5 } & & B & $\begin{array}{c}\text { Std. } \\
\text { Error }\end{array}$ & Beta & \\
\hline 1 (Constant) &, 500 &, 289 & & 0,572 \\
$\begin{array}{l}\text { application of } \\
\begin{array}{l}\text { accounting } \\
\text { information systems } \\
\text { internal control }\end{array}\end{array}$ &, 334 &, 170 &, 298 & \\
&, 492 &, 148 &, 503 & \\
\end{tabular}

a. Dependent Variable: employee performance

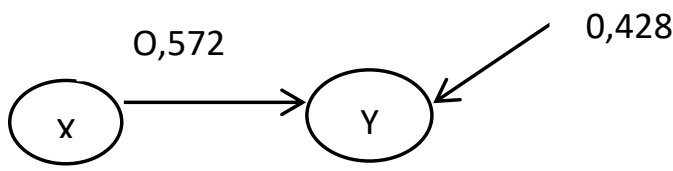

Figure 2. Causal Model in Path Analysis

$Y=0,298 X_{1}+0,503 X_{2}+0,428$

0,765

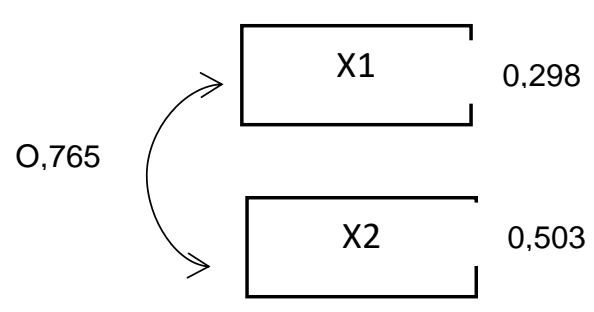

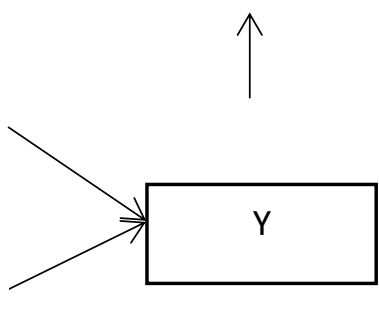

Figure 3. The Influence of the Application of Accounting Information Systems and Internal Controls on Employee Performance

Submitted: November 03, 2020; Accepted: November 10, 2020; 
JASa (Jurnal Akuntansi, Audit dan Sistem Informasi Akuntansi)

Vol. 4 No. 3/ December 2020

ISSN 2550-0732 print / ISSN 2655-8319 online

Table 11. Results of recapitulation of calculations

\begin{tabular}{|c|c|c|c|c|c|c|}
\hline \multirow[t]{2}{*}{ Variable } & \multirow[t]{2}{*}{$\begin{array}{l}\text { Coefficient } \\
\text { Path }\end{array}$} & \multirow[t]{2}{*}{ Direct Effect } & \multicolumn{2}{|c|}{$\begin{array}{l}\text { Indirect Effect } \\
\text { (through) }\end{array}$} & \multirow[t]{2}{*}{$\begin{array}{l}\text { Indirect } \\
\text { Effect } \\
\text { (through) }\end{array}$} & \multirow[t]{2}{*}{ Total } \\
\hline & & & $X_{1}$ & $X_{2}$ & & \\
\hline $\mathrm{X} 1$ & 0,298 & $8,9 \%$ & & $\begin{array}{l}11,5 \\
\%\end{array}$ & $11,5 \%$ & $20,3 \%$ \\
\hline $\begin{array}{l}\text { X2 } \\
\text { Total Effe }\end{array}$ & 0,503 & $25,3 \%$ & $11,5 \%$ & & $11,5 \%$ & $\begin{array}{l}36,8 \% \\
57,1 \%\end{array}$ \\
\hline
\end{tabular}

Source: Results of Data Processing

Based on the table above, it can be seen that the accounting information system application variable $(X 1)$ has a direct effect of $8.9 \%$ and an indirect effect through its relationship with internal control (X2) of $11.5 \%$. Furthermore, the total effect of the application of accounting information systems (X1) on employee performance $(Y)$ is $20.3 \%$. Internal control variable $(\mathrm{X} 2)$ has a direct effect of $25.3 \%$ and an indirect effect through its relationship with the application of the accounting information system (X1) of $11.5 \%$. Furthermore, the total effect of internal control (X2) on employee performance $(\mathrm{Y})$ is $36.8 \%$. The total effect between the application of the accounting information system (X1) and the internal control variable (X2) on employee performance $(\mathrm{Y})$ obtained R2 value of $20.3 \%+36.8 \%=57.1 \%$ while the rest $(\varepsilon 1)$ or other variables not studied which affected employee performance amounted to $42.9 \%$.

\section{Hypothesis testing}

The t test results can be seen in the following:

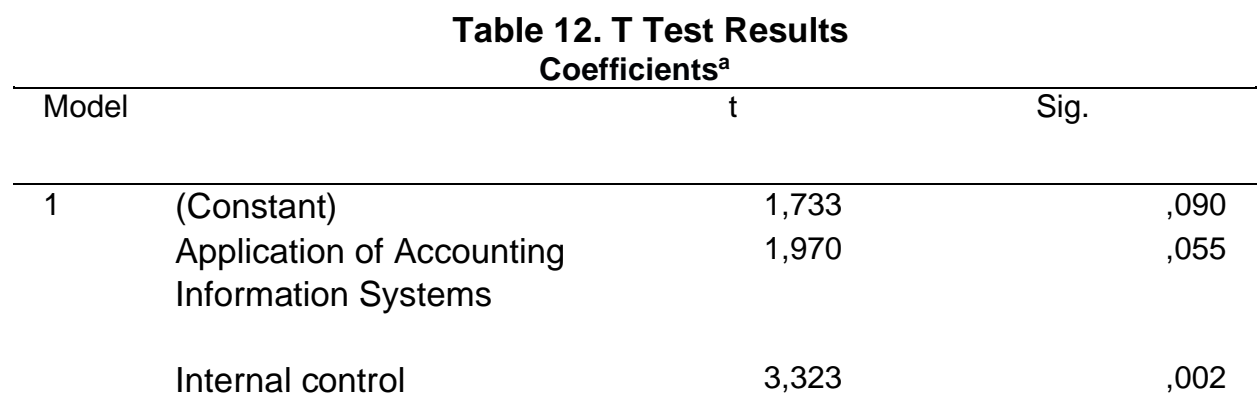

a. Dependent Variable: Employee performance

Based on the table above, it can be concluded that the results are as follows:

The estimated value of the variable application of the accounting information system with a significance of 0.055 and a value of tcount of 1.970 . The significance value is $0.055>0.005$ and tcount $1.970 \leq$ 2.014, then HA is rejected, meaning that the accounting information system application variable has no effect on employee performance. The estimated value of the internal control variable with a significance of 0.002 and a value of tcount of 3.323. The significance value is $0.002<0.005$ and the tcount is $3.323 \geq$ 2.014 , then $\mathrm{HA}$ is accepted, meaning that internal control has a significant effect on employee performance.

\section{CONCLUSION}

This study aims to determine the effect of the application of accounting information systems and internal controls 
on employee performance at PT BPR Kerta Raharja Bandung Regency. Based on the research results, the following conclusions can be drawn: Application of Accounting Information Systems has no effect on Employee Performance, because even though the availability of computers at PT. BPR Kerta Raharja, Bandung Regency, is not in accordance with the number of employees, but on the employee's performance, data entry is carried out by employees on time in accordance with company regulations. Internal control has a significant effect on employee performance, because internal control has carried out the company's vision and mission well so that every employee has a friendly and courteous attitude to other employees and employees can respect their superiors at PT. BPR Kerta Raharja, Bandung Regency.

\section{REFERENCES}

Bangun, Wilson. (2012). Manajemen Sumber Daya Manusia. PT Gelora Aksara Pratama.

Dimyati, Johni. (2013). Metodologi Penelitian Pendidikan dan Aplikasinya pada Pendidikan Anak Usia Dini (PAUD). Jakarta: Kencana.

Ghozali, Imam. (2016). Aplikasi Analisis Multivariate dengan Program IBM SPSS 23. Cetakan ke-8. Semarang: Badan Penerbit Universitas Diponegoro.

Sari, N. Z. M. dan Efendi, R. (2017). Sistem Informasi Akuntansi. Cetakan pertama. Bandung: FEKOM UNLA PERSS

Sugiyono. (2017). Metode Penelitian Bisnis. Bandung: Alfabeta.

Sugiyono. (2017). Metode Penelitian Kuantitatif, Kualitatif, dan $R \& D$. Bandung: Alfabeta.

Sujarweni, V. Wiratna. (2015). Metode Penelitian - Bisnis \& Ekonomi. Yogyakarta: Pustaka Baru Press.

Susanto, Azhar. (2013). Sistem Informasi Akuntansi Struktur Pengendalian
Resiko Pengembangan. Bandung: Lingga Jaya

Binilang, N. N. (2017). "Pengaruh Pengendalian Internal dan Gaya Kepemimpinan Terhadap Kinerja Karyawan pada Hotel Boulevard Manado". Jurnal Ekonomi dan Bisnis Universitas Sam Ratulangi Manado.

Kassaydina, V. C. (2018). "Pengaruh Kualitas Sistem Informasi Akuntansi Terhadap Kinerja Karyawan". Jurnal Akuntansi STIE Multi Data Palembang. 